\title{
SIMPLIFIED SEISMIC ANALYSIS OF ANCIENT CHURCHES AT A TERRITORIAL SCALE
}

\section{D’Amato M. ${ }^{1}$, Formisano A. ${ }^{2}$, Gigliotti R. ${ }^{3}$, Laguardia R. ${ }^{3}$}

${ }^{1}$ DICEM - Dept. of European and Mediterranean Cultures: Architecture, Environment, Cultural Heritages, University of Basilicata, Via Lanera, 75100 Matera, Italy

michele.damato@unibas.it

${ }^{2}$ Dept. of Structures for Engineering and Architecture, University of Naples "Federico II",

Piazzale Tecchio 80, 80125 Naples, Italy

antoform@unina.it

${ }^{3}$ DISG - Dept. of Structural Engineering, "Sapienza" University of Rome,

Via Eudossiana 18, 00184 Rome, Italy

e-mail: \{raffaele.laguardia, rosario.gigliotti\}@uniroma1.it

\begin{abstract}
An overview of some simplified methods for assessing the seismic performance of ancient churches is presented in this paper. In particular, the simplified methods proposed by the current Italian directive containing the guidelines for assessment and reduction of cultural heritage seismic risk are analyzed. These methods have an increasing precision level and they may be applied as well in sequence at a different scale for screening and identifying the present priorities and, consequently, for designing the required interventions. The work presented in this paper concludes showing the applications on some case studies, too.
\end{abstract}

Keywords: Ancient masonry churches, cultural heritage, monuments, seismic vulnerability, simplified methods. 


\section{INTRODUCTION}

Nowadays, the seismic protection of cultural heritage is a topic of great interest within the scientific community. The recent seismic events hitting many countries all over the world (L'Aquila 2009, Italy; Christchurch 2010, New Zealand; Tohoku 2011, Japan; EmiliaRomagna 2012, Italy; Lamjung 2015, Nepal; Middle-Italy 2016, Italy) have further highlighted the significant vulnerabilities of these earthquake-prone artefacts. Thus, it is necessary to act for protecting those assets and to reduce the losses due to seismic events. The data provided by the World Bank [1] show that the cost of natural disasters is increasing in an uncontrolled way, reaching about 652 billion of US dollars during the 90's of the last century. In [2] it has been estimated that the cost to the global economy is about 50 billion of US dollars per year. Regarding this aspect, it should be observed that only one third of this global expense is used to predict and to mitigate disasters, while the other two thirds are the direct cost of repairing damages.

According to these observations, it is continuously growing the need to develop reliable methods in order to allow planning of interventions aimed at protection and conservation of cultural properties. This absolute need is evidenced in many worldwide documents provided by many international bodies [3]-[6].

Recently, many efforts of scientific community have been addressed in order to evaluate the actual seismic risk of cultural heritage, by exploiting limited financial and time resources. Among the others it is worth to note the studies proposed in [16] - [21] for masonry buildings and churches, and in [22] - [23] for old masonry bridges. In addition, such tools should allow the identifications of future interventions also pursuing the possibility of realizing light and progressive interventions to be modulated over the structure life-time. This design criterion is the approach of the Italian directive [7], providing three different analysis levels (i.e. namely $L V 1, L V 2$ and $L V 3$ ) for seismic assessment of cultural heritage. The multilevel approach allows to perform preliminary analyses using easily available data and simple calculation tools. Subsequently, once determined the intervention priorities, it is possible to perform, where required, more complex analyses with detailed investigations. The first two levels are based on simplified analyses and allow a rapid assessment of seismic vulnerability.

In this article the simplified method indicated within the Italian Directive [7] is applied to a series of case studies. In addition, also a new simplified method is applied [8], it being proposed as a Level of Evaluation 0 (LV0) in according to the Italian guidelines. This method has the advantage to be very simple and to provide a first estimation not only of seismic vulnerability, but also of seismic risk at territorial scale. Therefore, it results very interesting in order to provide a very fast appraisal method useful as decision-making tool, requiring only qualitative and historical information of churches.

The chosen case studies consist of ancient masonry churches belong to the Historical Centre of Matera, recognized as UNESCO site since 1993. More information about the considered churches may be found in [9].

\section{LV1 METHOD PROPOSED IN THE ITALIAN DIRECTIVE}

This method represents, in accordance with the Italian Directive [7], the most simplified procedure for monumental churches, particularly suitable for territorial scale evaluations. It only requires in situ visual inspections able to estimate, by the means of a global vulnerability index, the seismic performance in terms of acceptable ground acceleration. This procedure does not allow of designing any structural intervention. The vulnerability index $i_{v}$ may be calculated as follows: 


$$
i_{v}=\frac{1}{6} \frac{\sum_{k=1}^{28} \rho_{k}\left(v_{k i}-v_{k p}\right)}{\sum_{k=1}^{28} \rho_{k}}+\frac{1}{2}
$$

where $\rho_{k}$ is the weight of each collapse mechanism (corresponding to 0 for the mechanisms not present or not active, or ranging between 0.5 and 1 in the other cases), $v_{k i}$ and $v_{k p}$ are scores assigned to the $k$-th considered mechanism related to evaluated vulnerability and to any seismic-resistant device, respectively. The weights are equal to 1 for the most important macro-elements regarding the seismic behaviour of a church (such as façade overturning, nave longitudinal transversal response, triumphal arch transversal response, etc.), while secondary mechanisms (such as prothyrum - narthex response, mechanisms of transepts and chapels) may have a weight comprised between 0.5 and 1 [7]. The so-calculated $i_{v}$ may vary between 0 and 1 .

By knowing the vulnerability index $i_{v}$, a ground acceleration corresponding to achievement of Damage Limit State $(D L S)$ and Life-Safety Limit State $(L S L S)$ may be estimated by applying the following equations, both established on a statistical basis:

$$
\begin{aligned}
& a_{D L S} S=0.025 \cdot 1.8^{2.75-3.44 i_{v}}[g] \\
& a_{L S L S} S=0.025 \cdot 1.8^{5.1-3.44 i_{v}} \quad[g]
\end{aligned}
$$

\section{SIMPLIFIED SEISMIC ASSESSMENT METHOD AT A TERRITORIAL SCALE}

The new simplified seismic assessment applied in this paper has been originally proposed in [8] for seismic risk assessment, and then subsequently validated and applied as well for vulnerability assessment in [9] and [10]. In general, the method is based on the use of three different tools; each of them allows the assessment of one of the three components that contribute to the seismic risk assessment, expressed, as known, through the following expression:

$$
R=H \times V \times E
$$

where $H$ is the hazard, $V$ is the vulnerability, and $E$ is the exposed elements or assets at risk.

The three tools (Tool 1, Tool 2 and Tool 3) are briefly described in the following:

- Tool 1: it allows the assessment of the exposition factor $E$ of Eq. 4. It assesses the cultural value of the asset by considering the conservation documents and the classifications of the investigated cultural heritage;

- Tool 2: it allows the assessment of the hazard factor $H$ of Eq. 4. The seismic hazard score of the artefact can be obtained by considering different available sources, such as, among the others, [5], [6] and [11].

- Tool 3: it allows the assessment of the seismic vulnerability factor $V$. The seismic vulnerability is evaluated by considering some simplified methods already available in the literature, such as, among the others, [12] and [13].

This method may be used even for indirectly assessing the seismic vulnerability. Unless the exposition factor $E$ of Eq. 1, within the same territorial area the seismic risk increases as seismic vulnerability increases [8], [9] and [10]. The final score is obtained as follows:

$$
R=[H+1] \times V
$$

where the hazard score is being added to unity for obtaining the resulting score $R$ greater than one. Therefore, for the scope of this paper, hereinafter are briefly described only the Tool 2 and Tool 3 (valuation of the $H$ and $V$ scores). More details about the Tool 1 may be found elsewhere [8]. 
- Tool 2: The hazard scores is obtained by considering different kinds of threats by dividing them on the basis of their frequency of occurrence in "sporadic events" and "continuous processes". Among the "sporadic events", is kept in count the seismic action, expressed through the maximum Mercalli Intensity, considering the eventual landslide or rock fracture as a consequence of an earthquake. The "continuous processes" kept in count are: a) rainfall erosion, due to the precipitations amount depending on coastal distance, relative humidity, direction and speed of prevailing winds; b) physical stress to assess the material damage provoked by temperature oscillations as, for instance, particles water icing with a consequent disintegration or cracking of materials; c) air pollution associated to traffic of vehicles, airplanes and boats, producing dissolution by acid rainfalls; d) the socio-organizational threat analysing the overload or damage on the monuments for the presence of intensive tourism and possible vandalism; e) demographic decline provoking monuments abandonment and maintenance lack.

The assessment of the relevance of each threat and its potential dangerousness is done by using existing documents and other evidences reporting damages occurred in the past. As an alternative, the damage estimation may be done on available literature data.

For each considered threat, three damage levels are considered and associated to a damage score, as reported in Table 1. The resulting seismic hazard score is a dimensionless parameter, ranging between 0 and 1 , which is calculated as follows:

$$
\mathrm{H}=\sum_{k=1}^{7} h_{k, i}
$$

- Tool 3: the seismic vulnerability is assessed by considering several aspects that can be listed as follows: a) foundation system and building position, in order to consider potential weaknesses or deficiencies of foundations; b) plan and elevation irregularity, that may increase, as known, the vulnerability of the building against earthquakes; c) distance between walls, by considering wall slenderness, out of plumb, excessive length in plan between two transversal walls and other potential weaknesses; d) non structural elements, by considering potential failures of hanged elements or other accessories; e) roof configuration, by evaluating the roof deformability, its connection to the walls and the effects of thrusts on the walls; f) conservation status, by considering eventual existing damages and the global and local conservation situations; g) fire vulnerability.

For each parameter, four different vulnerability levels $(A, B, C$ and $D)$ are considered. The level $A$ corresponds to absent (or very low) vulnerability, whereas the level $D$ is representative of a very high vulnerability. The scores associated to each vulnerability index and the related weights are reported in Table 2 . The vulnerability factor $V$ is then calculated as follows:

$$
\mathrm{V}=\sum_{k=1}^{13} \rho_{k} v_{k, i}
$$

where $v_{k, i}$ is the vulnerability score of the $k$-th parameter and $\rho_{k}$ the associated weight.

Table 1-Seismic hazard scoring [9].

\begin{tabular}{|c|l|c|c|c|}
\hline \multicolumn{2}{|c|}{ Threats } & \multicolumn{3}{c|}{ Severity of damage $\mathbf{h}_{\mathbf{k}, \mathbf{i}}$} \\
\cline { 3 - 5 } \multicolumn{2}{|c|}{} & $\begin{array}{c}\text { No damage/ } \\
\text { No hazard }\end{array}$ & Low or gradual & Catastrophic \\
\hline \multirow{2}{*}{$\begin{array}{c}\text { Sporadic } \\
\text { events }\end{array}$} & Seismic action & 0 & 0.20 & 0.40 \\
\cline { 2 - 5 } & $\begin{array}{l}\text { Landslide or rock frac- } \\
\text { ture }\end{array}$ & 0 & 0.15 & 0.25 \\
\hline \multirow{2}{*}{$\begin{array}{c}\text { Continuous } \\
\text { processes }\end{array}$} & Erosion & 0 & 0.05 & 0.10 \\
\cline { 2 - 5 } & Physical stress & 0 & 0.05 & 0.10 \\
\cline { 2 - 5 } & Air pollution & 0 & 0.01 & 0.05 \\
\hline
\end{tabular}


D’Amato M., Formisano A., Gigliotti R., Laguardia R.

\begin{tabular}{|l|l|l|l|l|}
\hline & Socio - organizational & 0 & 0.01 & 0.05 \\
\cline { 2 - 4 } & Demographic decline & 0 & 0.01 & 0.05 \\
\hline
\end{tabular}

Table 2 - Parameters scores and weights for seismic vulnerability evaluation [9].

\begin{tabular}{|c|c|c|c|c|c|c|}
\hline \multicolumn{2}{|r|}{ Parameter } & \multicolumn{4}{|c|}{ Vulnerability $\mathbf{v}_{k, i}$} & \multirow{3}{*}{$\begin{array}{c}\text { Weight } \boldsymbol{\rho}_{\mathbf{k}} \\
0.75\end{array}$} \\
\hline & & $\mathbf{A}$ & B & $\mathrm{C}$ & D & \\
\hline 1 & $\begin{array}{l}\text { Position of the building } \\
\text { and foundations }\end{array}$ & 0 & 1.35 & 6.73 & 12.12 & \\
\hline 2 & $\begin{array}{l}\text { Floor plan configuration } \\
\text { or geometry }\end{array}$ & 0 & 1.35 & 6.73 & 12.12 & 0.5 \\
\hline 3 & Elevation configuration & 0 & 1.35 & 6.73 & 12.12 & 1.0 \\
\hline 4 & Distance between walls & 0 & 1.35 & 6.73 & 12.12 & 0.25 \\
\hline 5 & Non-structural elements & 0 & 1.35 & 6.73 & 12.12 & 0.25 \\
\hline 6 & $\begin{array}{l}\text { Type and organization of } \\
\text { the resistant system }\end{array}$ & 0 & 1.35 & 6.73 & 12.12 & 1.5 \\
\hline 7 & $\begin{array}{l}\text { Quality of the resistant } \\
\text { system }\end{array}$ & 0 & 1.35 & 6.73 & 12.12 & 0.25 \\
\hline 8 & Horizontal structures & 0 & 1.35 & 6.73 & 12.12 & 1.0 \\
\hline 9 & Roof configuration & 0 & 1.35 & 6.73 & 12.12 & 1.0 \\
\hline 10 & Conservation status & 0 & 1.35 & 6.73 & 12.12 & 1.0 \\
\hline 11 & Environmental alterations & 0 & 1.35 & 6.73 & 12.12 & 0.25 \\
\hline 12 & $\begin{array}{l}\text { Construction system alter- } \\
\text { ations }\end{array}$ & 0 & 1.35 & 6.73 & 12.12 & 0.25 \\
\hline 13 & Fire Vulnerability & 0 & 1.35 & 6.73 & 12.12 & 0.25 \\
\hline
\end{tabular}

\section{CASE STUDIES}

The seismic performance methods exposed herein has been applied to six churches located in the city centre of Matera. The chosen churches, shown in Table 1, are: SS Maria della Bruna, San Giovanni Battista, San Pietro Caveoso, San Rocco, San Francesco d'Assisi and Sant'Agostino. All churches are characterized by the same construction material: masonry made by calcarenite blocks. This material is a limestone sedimentary rock, improperly called "tufo", although it has not a volcanic origin. This soft rock is employed in blocks with a quite often standard dimensions (length $=45-60 \mathrm{~cm}$, height $=25-27 \mathrm{~cm}$, width $=20-25 \mathrm{~cm}$ ). The blocks are combined with mortar joints and used for both vertical walls and vaults. All the churches have a one-nave plan configuration, with the exception of San Giovanni Battista and San Pietro Caveoso; the roof structures are made of calcarenite in all cases with the exception of San Pietro Caveoso and San Francesco d'Assisi, that have a wooden roof structure. All the churches have a one-floor elevation configuration. In none of the considered churches are present structural interventions to reduce the structural vulnerabilities due to earthquakes. Details about the considered churches may be found in [9], [10], [14], [15].

\section{APPLICATION OF THE METHOD TO THE CASE STUDIES}

The simplified methods previously described have been applied to the chosen case studies. In particular, as for the new simplified $L V O$ method considered, the obtained vulnerability $(V)$, hazard $(H)$ and risk $(\mathrm{R})$ scores are numerically reported in Table 3. The lower risk score (i.e. $\mathrm{R}=22.15$ ) is obtained for the Matera's cathedral (SS Maria della Bruna), while the higher one is obtained for the $S$. Agostino church (i.e. R=50.49). These results are compared with the ones obtained with the LV1 method in Figure 2. More details about the LV1 evaluation are reported in [9] and [14]. As far as the $L V 0$ results, the resulting seismic scores $\left(R_{i}\right)$ are divided by the minimum one $\left(R_{\min }\right)$, and the obtained ratios $\left(R_{i} / R_{\min }\right)$ are represented in ascending or- 
der. Whereas, the results of the $L V 1$ method are represented through the dimensionless return period $\left(T_{i, L S L S} / T_{L S L S m i n}\right)$ and the dimensionless ground acceleration capacity $\left(a_{i, L S L S} / a_{L S L S m i n}\right)$ for the Life Safety Limit State $(L S L S)$. Both these dimensionless parameters are an indirect value of the relative vulnerability. It results that the higher the ratio the lower the seismic vulnerability. As it can be clearly observed, the results between the two methods are in very good agreement, confirming the capability of the simplified $L V 0$ approach to provide a first and fast classification of the seismic vulnerability at a territorial scale for a large group of ancient masonry churches.

SS Maria della Bruna

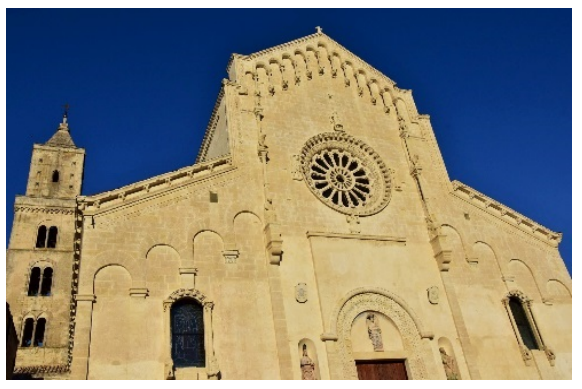

San Rocco

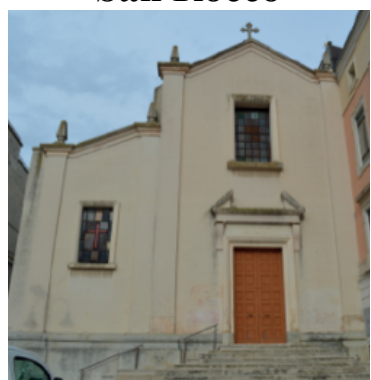

San Giovanni Battista

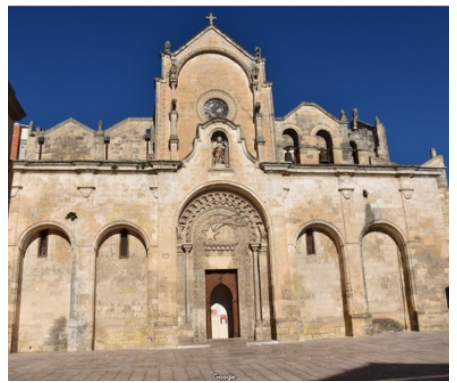

San Francesco d'Assisi

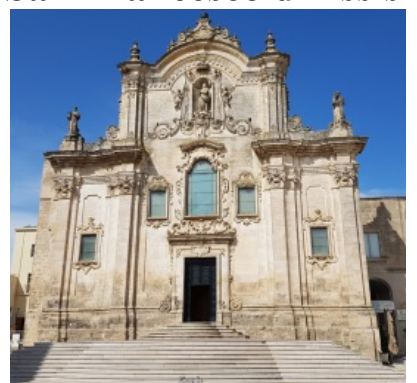

San Pietro Caveoso

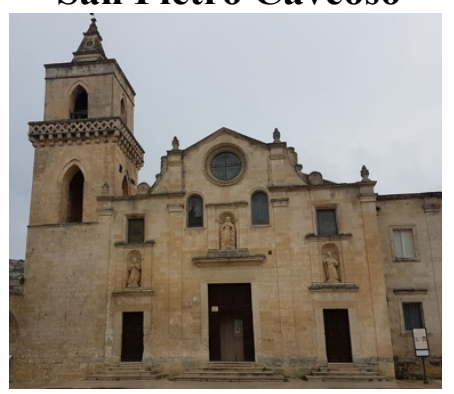

Sant'Agostino

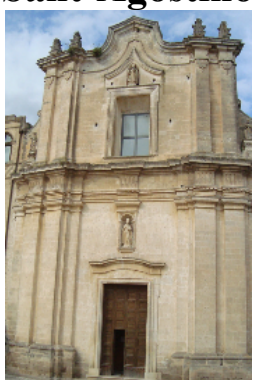

Figure 1 - Front views of the considered case studies.

\section{CONCLUSIONS}

In this paper a comparison among two different simplified methods for seismic assessment of old masonry churches has been shown. The methods are easy to be applied and allow, with a different knowledge level of a structure, to perform an appraisal at a territorial level. The application to six case studies has confirmed that the new simplified method, named $L V O$ according to the Italian Directive, is a fast tool for seismic assessment capable of ranking the priorities to be investigated more in detail within a multi-level seismic assessment methodology. As for the obtained results, it has emerged that the less vulnerable church is SS Maria della Bruna, while the most vulnerable one is Sant'Agostino church.

Table 3 - Seismic risk assessment according to the simplified procedure [8].

\begin{tabular}{|c|c|c|c|c|c|c|}
\hline \multicolumn{2}{|c|}{ Macro-element } & $\begin{array}{c}\text { SS Maria } \\
\text { della Bruna }\end{array}$ & $\begin{array}{c}\text { San } \\
\text { Pietro } \\
\text { Caveoso }\end{array}$ & $\begin{array}{c}\text { San } \\
\text { Rocco }\end{array}$ & $\begin{array}{c}\text { San } \\
\text { Frances- } \\
\text { co } \\
\text { d'Assisi }\end{array}$ & $\begin{array}{c}\text { San Giovanni } \\
\text { Battista }\end{array}$ \\
\hline 1 & Position and foundations & A & A & B & A & A \\
\hline 2 & Floor plan configuration & C & C & C & D & C \\
\hline 3 & Elevation configuration & A & A & A & A & A \\
\hline 4 & Distance between walls & C & D & D & D & D \\
\hline 5 & Non-structural elements & C & D & D & D & D \\
\hline 6 & Type-organization of R.S. & B & A & B & B & B \\
\hline 7 & Quality of the R.S. & A & A & A & A & A \\
\hline
\end{tabular}




\begin{tabular}{|c|c|c|c|c|c|c|}
\hline 8 & Horizontal structures & $\mathrm{A}$ & $\mathrm{A}$ & $\mathrm{A}$ & $\mathrm{A}$ & $\mathrm{A}$ \\
\hline 9 & Roofing & $\mathrm{C}$ & $\mathrm{C}$ & $\mathrm{C}$ & $\mathrm{C}$ & $\mathrm{C}$ \\
\hline 10 & Conservation status & $\mathrm{A}$ & $\mathrm{A}$ & $\mathrm{A}$ & $\mathrm{B}$ & $\mathrm{A}$ \\
\hline 11 & Environmental alterations & $\mathrm{A}$ & $\mathrm{B}$ & $\mathrm{A}$ & $\mathrm{A}$ & $\mathrm{A}$ \\
\hline 12 & $\begin{array}{c}\text { Construction system altera- } \\
\text { tions }\end{array}$ & $\mathrm{A}$ & $\mathrm{A}$ & $\mathrm{A}$ & $\mathrm{A}$ & $\mathrm{A}$ \\
\hline 13 & Vulnerability to fire & $\mathrm{B}$ & $\mathrm{B}$ & $\mathrm{B}$ & $\mathrm{B}$ & $\mathrm{B}$ \\
\hline Seismic vulnerability score (V) & $\mathbf{1 5 . 8 2}$ & $\mathbf{1 6 . 8 3}$ & $\mathbf{1 9 . 5 3}$ & $\mathbf{2 2 . 5 6}$ & $\mathbf{3 3 . 6 6}$ \\
\hline 1 & Maximum Mercalli Intensity & 0.2 & 0.20 & 0.20 & 0.20 & 0.20 \\
\hline 2 & Landslides/rock fracture & 0.05 & 0.15 & 0 & 0 & 0 \\
\hline 3 & Erosion & 0.05 & 0.05 & 0 & 0.05 & 0.05 \\
\hline 4 & Physical stress & 0 & 0 & 0 & 0 & 0 \\
\hline 5 & Pollution & 0.05 & 0.05 & 0.05 & 0.05 & 0.05 \\
\hline 6 & Socio-organizational & 0.05 & 0.05 & 0.05 & 0.05 & 0.05 \\
\hline 7 & Demographic decline & 0 & 0 & 0 & 0 & 0 \\
\hline & $\begin{array}{c}\text { Seismic hazard score } \\
\text { (H+1) }\end{array}$ & $\mathbf{1 . 4 0}$ & $\mathbf{1 . 5 0}$ & $\mathbf{1 . 3 0}$ & $\mathbf{1 . 3 5}$ & $\mathbf{1 . 3 5}$ \\
\hline & $\begin{array}{c}\text { SEISMIC RISK [V } \mathbf{x} \\
\text { (H+1)] }\end{array}$ & $\mathbf{2 2 . 1 5}$ & $\mathbf{2 5 . 2 5}$ & $\mathbf{2 5 . 3 9}$ & $\mathbf{3 0 . 4 6}$ & $\mathbf{2 5 . 0 0}$ \\
\hline
\end{tabular}

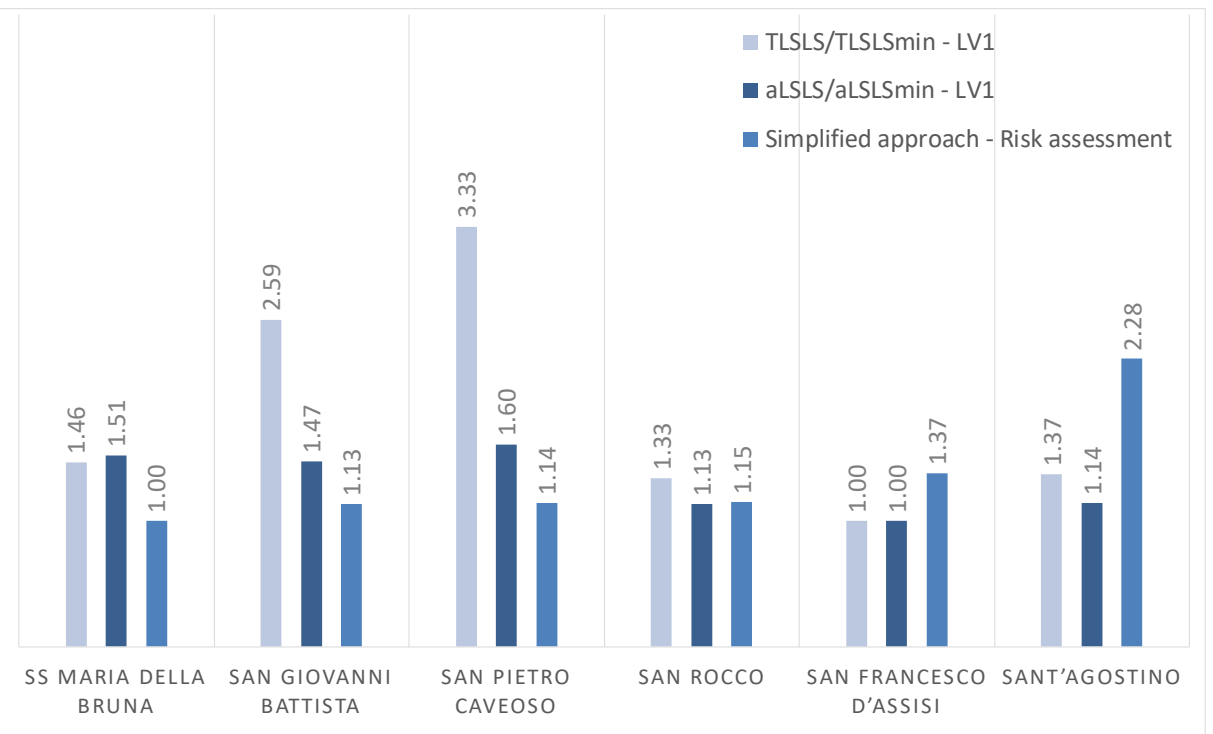

Figure 2 - Comparison among the results obtained with the LV0 and LV1 methods for the case studies considered.

\section{REFERENCES}

[1] World Bank Indipendent Evaluation Group (IEG), Hazard of nature, risks to development. An IEG evaluation of World Bank assistane for natural disasters. The World Bank, 2011.

[2] D. C. Alexander, Natural disasters. Springer, 2017. 
[3] ICOMOS, Risk Preparedness. Heritage at risk. UNESCO-ICOMOS Documentation Centre, 2005.

[4] B. M. Feilden, J. Jokilehto, Management guidelines for world cultural heritage sites. ICCROM, 1998.

[5] CENAPRED, Diagnóstico de Peligros e Identificación de Riesgos de Desastres en México. Atlas Nacional de Riesgos de la República Mexicana, CENAPRED, 2014.

[6] ISCR, Carta del Rischio. http://www. cartadelrischio.it, 2017.

[7] D.P.C.M. 9/2/2011, Valutazione e riduzione del rischio sismico del patrimonio culturale con riferimento alle Norme tecniche per le costruzioni di cui al decreto del Ministero delle infrastrutture e dei trasporti del 14 gennaio 2008. Italian Presidency of the Council of Ministry, 2011.

[8] D. Díaz Fuentes, Diseño de herramientas de evaluación del riesgo para la conservación del patrimonio cultural inmueble. Aplicación en dos casos de estudio del norte andino chileno. México, Escuela Nacional de Conservación, Restauración y Museología , 2016.

[9] M. D’Amato, M. Laterza, D. Diaz Fuentes, Simplified Seismic Analyses of Ancient Churches in Matera's Landscape. International Journal of Architectural Heritage, 1$20,2018$.

[10] Fuentes, D. D., D'Amato, M., Laterza, M., 2019. Seismic Vulnerability and Risk Assessment of Historic Constructions: The Case of Masonry and Adobe Churches in Italy and Chile. SAHC 2018, 11th International Conference on Structural Analysis of Historical Constructions. 18, pp. 1127-1137. Cusco, Perù, 11-13 September 2018: RILEM Bookseries.

[11] M. R. Degg, D. K. Chester, Seismic and volcanic hazards in Peru: changing attitudes to disaster mitigation. Geographical Journal , 171 , 125-145 , 2005.

[12] DGPTA, Manuale Per Il Rilevamento., 2007.

[13] Instituto Nacional de Normalizazion INNEstructuras-Intervención de construcciones patrimoniales de tierra cruda-Requisitos del Proyecto Estructural. Santiago de Chile, 2013.

[14] M. D'Amato, R. Gigliotti, R. Laguardia, Comparative seismic assessment of ancient masonry churches. Frontiers in Built Environment, 2019. (under review).

[15] Ramirez, E., Lourenco, P. B., \& D'Amato, M., 2019. Seismic assessment of the Matera Cathedral. SAHC 2018, 11th International Conference on Structural Analysis of Historical Constructions (pp. 1346-1354). Cusco, Perù, 11-13 September 2018: RILEM Bookseries.

[16] Sarhosis, V., Milani, G., Formisano, A., Fabbrocino, F., 2018. Evaluation of different approaches for the estimation of the seismic vulnerability of masonry towers, Bulletin of Earthquake Engineering, 16 (3), pp. 1511-1545. DOI: 10.1007/s10518-017-0258-8.

[17] Krstevska, L., Tashkov, L., Naumovski, N., Florio, G., Formisano, A., Fornaro, A., Landolfo, R., 2010. In-situ experimental testing of four historical buildings damaged during the 2009 L'Aquila earthquake, COST ACTION C26: Urban Habitat Constructions under Catastrophic Events - Proceedings of the Final Conference, pp. 427-432. 
[18] Formisano, A., Vaiano, G., Fabbrocino, F., Milani, G., 2018. Seismic vulnerability of Italian masonry churches: The case of the Nativity of Blessed Virgin Mary in Stellata of Bondeno, Journal of Building Engineering, Vol. 20, pp. 179-200. DOI: 10.1016/j.jobe.2018.

[19] Caprili, S., Mangini, F., Salvatore, W., Bevilacqua, M.G., Karwacka Codini, E., Squeglia, N., Barsotti, R., Bennati, S., Scarpelli, G., Paci, S., Iannelli. P., 2017. A knowledgebased approach for the structural assessment of cultural heritage, a case study: La Sapienza Palace in Pisa. Bulletin of Earthquake Engineering, Vol. 15, pp. 4851-4886, DOI: 10.1007/s10518-017-0158-y.

[20] Luchin, G., Luis, L. F., D'Amato, M., 2018. Sonic Tomography for Masonry Walls Characterization. International Journal of Architectural Heritage, Published on-line. https://doi.org/10.1080/15583058.2018.1554723.

[21] Lopez, S., D’Amato, M., Ramos, L., Laterza, M., Lourenco, P., 2019. Simplifies formulations for estimating the main frequencies of ancient churches. Frontiers Built Enviroment, Vol. 5:18., 1-15. doi: 10.3389/fbuil.2019.00018

[22] Laterza, M., D'Amato, M., Casamassima, V.M., 2017. Seismic performance evaluation of multi-span existing masonry arch bridge. AIP Conference Proceedings, 1863, art. no. 450010 .

[23] D’Amato, M., Laterza, M., Casamassima, V.M., 2017. Seismic performance evaluation of a multi-span existing masonry arch bridge. Open Civil Engineering Journal, 11 (11), pp. 1191-1207. 